\title{
AN ANALYSIS OF THE GAPS IN THE NEWLY ESTABLISHED SOUTH AFRICAN MILITARY OMBUD
}

\author{
Moses Montesh and Boitumelo Mmusinyane, \\ University of South Africa: College of Law ${ }^{1}$
}

\begin{abstract}
The South African Department of Defence and Military Veterans can be commended for having taken a bold step in an endeavour to establish an independent entity capable of conducting oversight of its military through the introduction of the Military Ombud Act. However, said Act seems not to adequately address pertinent issues experienced by the defence sector. These issues include who may submit a complaint, the independence of the Military Ombud (MO) and its accountability structure. Unless the Bill deals with these issues, we are likely to see dispossession of the public protector's investigation powers and the establishment of a mere toothless tiger. Under the current format of the Bill, the MO is likely to become the Minister's mouthpiece. It would deepen and marginalise military complainants' hope of finding a remedy in an independent structure capable of challenging some of the questionable military acts or omissions that have no substance while not achieving the exercise, enjoyment and fulfilment of military complainants' human rights in accordance with the 1996 Constitution of the Republic of South Africa.
\end{abstract}

\section{Introduction}

In general, an ombudsman is an institution exercising oversight of public

Scientia Militaria, South African Journal of Military Studies, Vol

41, Nr 1, 2013, pp. 91-110.

doi: $10.5787 / 41-1-1054$ administration and helping to ensure that the latter observes the principles and practices of good governance by dealing with complaints from the public regarding decisions, actions or omissions of the public administration. ${ }^{1}$

\footnotetext{
${ }^{1}$ Part of this article was presented at the South African Parliament as submissions in respect of the Military Ombudsman Bill of 2011 before the Parliament's Committee of Defence and Military Veterans on 17 August 2011 in Cape Town.
} 
However, most countries do not have a specialised ombudsman, as most prefer one institution investigating all types of complaints, including those originating from or about the military. South Africa (SA) has recently established its own Military Ombud $(\mathrm{MO})^{2}$ in terms of the Military Ombud $\mathrm{Act}^{3}$ to deal mainly with military complaints that were previously investigated by the Office of the Public Protector. ${ }^{4}$ This move was motivated by the uniqueness of the defence sector environment and the public protector's insufficiency and ineffectiveness in resolving complaints from the defence sector. ${ }^{5}$ South Africa's first MO was appointed on 14 May 2012 and this paves the way for the strengthening of democracy and dispute-resolution mechanisms within the South African armed forces. ${ }^{6}$ This article analyses the establishment of the MO in terms of the Act. ${ }^{7}$ The MO office is explored in terms of its importance in protecting matters affecting the military personnel in the performance of their duties and the way in which the MO office can contribute to a more efficient and accountable structure of the armed forces. Further, the article critically analyses the Act through a comparative approach to the MO's function, highlighting the advantages and shortcomings thereof.

\section{The rationale for establishing a MO}

As a point of departure, the MO is understood as a mechanism independent of the military command structure exercising the oversight of the defence sector and helping to ensure that it observes the principles and practice of good governance. ${ }^{8}$ According to Fleck, ${ }^{9}$ the MO can play a major role in the governance of the armed forces, such as promoting transparency and accountability within the armed forces without undermining the authority of the military chain of command, ensuring respect for the rule of law in the armed forces and strengthening public confidence and the reputation of the armed forces.

This role is vital, as modern militaries are becoming increasingly globalised. Many, if not all, states in Africa or anywhere else in the world either contribute or have contributed to international peacekeeping operations. Therefore, it must be acknowledged that the MO have to come to terms with an increasingly globalised world. In general terms, the MO addresses complaints about improper and abusive behaviour in the military as well as shortcomings in military procedures, and formulates recommendations for corrective action. ${ }^{10}$ However, it does not make defence policy or take decisions on operational issues. ${ }^{11}$ While the immediate purpose of the MO is to redress grievances and to encourage proper conduct of and within the defence sector, the broader role of the office is to enhance its efficiency and effectiveness by making it accountable and responsive to its constituencies. ${ }^{12}$ The role of the MO recognises the special nature of the employment relationship 
between members of the Defence Force and their employer, which extends into many facets of the lives of Defence Force members and their families.

In spite of the existing complaints procedures within the military, some countries around the world have specialised ombudsmen to address or deal with military complaints exclusively, including even systemic problems in the military. ${ }^{13}$ In this context, the value of an MO office can be seen $^{14}$ as an independent watchdog contributing to the democratic and civilian control of the armed forces; it reinforces the principles of good governance, civilian control and human rights within the barracks, ${ }^{15}$ it provides essential protection to individual armed forces personnel against violations of their rights, abuses of power or unfair decisions; it can also help military commanders to efficiently and effectively achieve internal changes and to improve the internal functioning of the armed forces; and it can have a positive impact on the quality of life of servicemen and on their morale (esprit de corps), which can help retain soldiers at a time of critical staff shortages.

Before analysing the South African MO, it is of significant value to examine the approach that has been adopted around the globe to deal with complaints emanating from the military as a whole.

\section{International Comparison}

As far as the structure and the competencies of ombudsmen are concerned, three main models are found around the globe: ${ }^{16}$

- Countries without an MO (e.g. Slovakia and Spain) or where the MO is integrated into the military (e.g. the Netherlands, the United Kingdom [UK] and Belgium);

- Countries that have an independent MO (e.g. Germany, Canada, Ireland and Norway); and

- Countries where the civilian ombudsman's responsibility also includes the military (e.g. Sweden, Denmark, Poland and as previously in SA).

The said models and the way in which they can be integrated into SA's MO approach are now analysed.

Countries without an MO (Slovenia and Spain) or with the MO integrated into the military (Netherlands, Belgium and the UK)

The majority of countries do not have an MO and this approach has the disadvantage of relying principally on the command structure for the administration of discipline within the military ranks. ${ }^{17}$ However, there is a risk that abuse and 
mistreatment of military personnel will go unpunished due to the lack of confidence in internal disciplinary procedures and due to the fear of retaliation by military commanders; therefore, the protection of human rights of servicemen may be at risk. The absence of an MO is often due to strong resistance to the introduction of such independent complaints mechanisms on the part of the chain of command. In the UK, for example, especially after the death of the four recruits at the Deepcut army barracks, there was an intense debate on the merits of establishing an alternative means of exercising external and independent oversight of the armed forces. ${ }^{18}$ The introduction of an MO with full investigative powers in respect of complaints and authority to make binding adjudications on them was recommended by both the Defence Committee of the House of Commons and the Deepcut Review Report (1995-2002). ${ }^{19}$ However, the Ministry of Defence did not accept this recommendation, "mainly on the grounds that military services already [had] procedures for dealing with the military complaints". ${ }^{20}$ Also, the proposal of extending the terms of reference of the Parliamentary Commissioner for Administration to permit him to deal with complaints from service personnel about administrative matters was refused. ${ }^{21}$

Instead, the legislation in 2006 introduced the Service Complaints Commissioner, appointed by the Defence Minister. His or her role is to supervise the investigation of complaints by the military and to report to the Defence Minister annually on the operation of these redress procedures. ${ }^{22}$ Often, the military chain of command tends to favour an oversight mechanism integrated into the military, as it appears to be more receptive to command and control issues and attentive to the need to protect the operational effectiveness of the military. ${ }^{23}$ Although it has the advantage of specialist knowledge of military life and issues, ${ }^{24}$ the integrated mechanisms may lack independence, as they are under the control of the military hierarchy, which, in turn, reduces the legitimacy of the complaints mechanism in the eyes of the complainants.

An inspector-general, as this mechanism is most often called, is usually involved in operational issues, and the incumbent is invariably a serving member of the military, which brings discomfort to his or her objectivity in the office. This is the case in the Netherlands, where the inspector-general of the armed forces has both an advisory and a mediation function. He or she also exercises the function of inspector for veterans. The main drawback of this approach is that the military performs the oversight function on itself and thus creates a potential conflict of interest and undermines confidence in the recommendations of the oversight body. ${ }^{25}$ In this respect, the introduction of legislation by the Ministry of Defence can be seen as an essential step towards addressing or complementing the already existing 
Individual Grievance Procedure by establishing an independent specialised investigation body to deal exclusively with military matters, similar to other countries that already have an independent MO.

Countries with an independent MO (Germany, Canada, Ireland and Norway)

As a separate institution, the laws of several countries do provide for an independent MO, such as the Parliamentary Ombudsman for the Norwegian armed forces, the Parliamentary Commissioner for the armed forces in Germany, the Ombudsman for National Defence and Canadian Forces, and the Ombudsman for the defence forces of Ireland. This means that the MO is impartial and independent of the Minister of Defence, the Department of Defence and the military authorities. ${ }^{26}$ In addition to having specialist knowledge of military matters, the main advantage of these ombudsmen is their credibility in the eyes of complainants, Parliament and the public. ${ }^{27}$ However the main disadvantage of their establishment seems to be that it is highly costly to run.

The Parliamentary Ombudsman for the Norwegian armed forces was established in 1952, making it the world's first Parliamentary MO, with its Ombudsman being elected and reporting directly to Parliament. ${ }^{28}$ The MO is impartial and independent of the Ministry of Defence and the military authorities and safeguards the rights of all members and former members of the armed forces. ${ }^{29}$ The Office of the Ombudsman for the National Defence and Canadian Forces was set up in 1998, following a public inquiry into the involvement of a Canadian airborne regiment in beating up, torturing and killing Somali youngsters during a peacekeeping mission in Somalia in $1992 .{ }^{30}$ One of the recommendations of the public inquiry was to strengthen the accountability of the Canadian Forces by setting up an independent review body. ${ }^{31}$

The Canadian MO office is a fully independent institution appointed by cabinet, but reporting to the Ministry of Defence. ${ }^{32}$ It deals with individual complaints initiated by military members, their families, the Ministry of Defence or upon its own initiative. ${ }^{33}$ Unlike in Germany, a complainant must, except in compelling circumstances, have attempted to resolve the complaint by referring it to the chain of command or the military grievance system before taking recourse to the MO. ${ }^{34}$ In Canada, members of the armed forces must make a complaint through internal structures before submitting a case to the MO. Upon conclusion of an investigation, the MO may make recommendations to the Minister of Defence, setting out measures that should be taken to rectify the situation. If the Minister's response to the MO's recommendations is unsatisfactory, the MO may issue a 
special report on the case. ${ }^{35}$ The MO may also conduct investigations into systemic issues, as, for example, in the framework of the Post-Traumatic Stress Disorder Initiative. ${ }^{36}$ The MO publishes an annual report that is tabled in Parliament by the Defence Minister and is debated by the relevant parliamentary committees, as well as special reports on specific investigations, when this is judged to be in the public interest. $^{37}$

The advantage of an independent military oversight mechanism is that it can devote its attention exclusively to military matters, thus developing specialised knowledge in the field. Its ability to issue public reports strengthens Parliament's oversight capacity and ensures greater transparency and accountability of the military. These are among the most significant examples of independent mechanisms for military oversight and have often been used as models by other countries, such as Ireland. ${ }^{38}$ The Irish Ombudsman for the defence forces is appointed by the President of Ireland on the recommendation of the government and reports to the Minister of Defence. ${ }^{39}$ The MO investigates complaints by members and former members of the defence forces. The MO's task is to ensure that members and former members of the permanent defence forces and reserve defence forces have a rigorous, independent and fair appeal for complaints they believe have not been adequately addressed by the internal military complaints process. ${ }^{40}$ The last model concerns an all-inclusive ombudsman dealing with all types of complaints regarding the country's public administration.

Countries where the civilian ombudsman's responsibility includes the military

In some countries, such as Sweden, Denmark and Poland, and previously SA, the military oversight function is that of a civilian ombudsman. A civilian ombudsman, in this case, has the advantage of having a strong appearance of independence and of ensuring equal treatment of military personnel and civilians. ${ }^{41}$ However, most often it may lack specific knowledge and credibility within the military. ${ }^{42}$ Furthermore, an excessive workload may cause significant delays in the resolution of cases. A solution to these problems could be to introduce specialisations within the Ombudsman's office, for example appointing a deputy ombudsman dealing specifically with military affairs.

In Sweden, the Ombudsman's work is subdivided into several areas of responsibility, including the armed forces, non-combatant national service and other cases relating to the Ministry of Defence. ${ }^{43}$ Sweden was the first country to establish an MO office. ${ }^{44}$ Later, in the $1980 \mathrm{~s}$, however, in the framework of general reform of the Swedish military, the responsibilities of the MO were incorporated into the 
responsibilities of the Parliamentary Ombudsman. ${ }^{45}$ In Denmark, an advisory system has been established to provide assistance and advice to soldiers and officers who feel that they have been subjected to discrimination or have been accused of discrimination. ${ }^{46}$ The system consists of advisers outside the military chain of command who perform this advisory function alongside their normal assignments. When exercising their advisory function, they report to a chief adviser in the Army's Personnel Command. ${ }^{47}$

The advisers provide guidance or, if necessary, assistance in formulating a complaint through the chain of command. ${ }^{48}$ The system does not constitute an external/independent complaint process in itself, and has the advantage of ensuring that soldiers' rights are not unduly differentiated from those of the population as a whole. ${ }^{49}$ The concentration of the ombudsman function in one office can also be less costly than having several specialised offices. However, civilian oversight mechanisms may lack the necessary expertise for dealing with the defence sector and may fail, due to the wide scope of its mandate, to focus attention on the particular problems facing military personnel. Currently, a military investigator within the Office of the Public Protector is responsible for investigating all complaints within the defence sector. However, the Ministry of Defence, seems to have found the mechanism of the Public Protector's office insufficient and ineffective to deal with the defence sector environment. This assertion may found a basis due to the involvement of the public protector in various public administrations in the national, provincial and local arena, including even parastatals such as Eskom, Telkom, the post office and Transnet. Therefore in establishing the MO, SA could draw from existing diverse experiences hereto referred in ensuring the MO has a more solid foundation than some of those shown to have some weakness despite dealing exclusively with the military.

\section{South African Perspective of the Military Ombud}

While the constitutional basis of an MO is the primary source of its strength (and, in a selective sense, its weakness), constitutionality of the rules of public administration itself is a prerequisite for its structural and operational security and effectiveness. ${ }^{50}$ The minimum characteristics that such an MO must have are: ${ }^{51}$

- Independence;

- Impartiality and fairness (i.e. transparency of procedures);

- Credibility of the review process; and

- Confidentiality. 
In terms of Section 195 of the Constitution, any national legislation must embrace the basic principles governing public administration, ${ }^{52}$ hence the establishment of the MO. Though not directly born from the Constitution, but through its own legislation, the MO attempts to fulfil this requirement; however, if it is to fully embrace the said principles it must address certain concerns raised by the authors hereunder to ensure that it does not become a toothless paper tiger.

Gaps in the Military Ombud Act

Who can complain? The current status of the Military Ombud Act with regard to complainants poses a threat to actual complainants and is likely to diminish the MO's functioning in the long term. As opposed to the Bill, ${ }^{53}$ the Act removed the definition of a complaint and thus brought uncertainty as to who can be regarded as complainants in terms of the Act. If to be included the list of complainants needs to reflect a variety of individuals permanently employed within the defence sector. Section 1 of the Defence Act No. 42 of 2002 only covers members and civilians employed under that visiting force to the exclusion for example of employees appointed in terms of the Public Service Act No. 103 of 1994. Therefore, any restrictive definition of complainants should as far as possible be avoided and a complainant definition must include military staff, civilians employed in the defence sector, former members and reserve members, and even disgruntled applicants. . ${ }^{54}$ Further, the Military Ombud Act needs to include as complainant anyone who, pursuant to a law or an agreement between SA and the state in which the SANDF is stationed for peacekeeping purposes has a complaint against an employee of the SANDF. The question that must be asked is whether the dispossession of the Public Protector's investigation powers also included civilian matters and how their complaints against the department would be dealt with. It is the authors' view that the Act should not discriminate against such civilians due to the nature of their employment within the defence sector; they need to be included in the Act as complainants. This would ensure that complaints emanating from the defence sector are dealt with properly by one institution only, which is what the Department of Defence intends to achieve by moving away from the jurisdiction of the Public Protector.

The need for the inclusion and extension of the list of complainants, in the Military Ombud Act, to address all complaints arising within the defence sector could arguably be based on the fact that even the definition of a member as contained in the Defence Force Act does provide protection to them and it is hoped that the established MO could close that gap left by the Defence Force Act. It cannot 
be ignored that our Department of Defence is also facing daunting challenges in the manner in which it administers its affairs or operates and treats its military personnel and those employed in terms of a public service appointment.

In addition, the Act seems to restrict the mandate of the $\mathrm{MO}^{55}$. Therefore, in order to ensure that the MO takes over fully from the Public Protector's mandate and conducts full military oversight, its mandate needs to be broadened to incorporate a broad spectrum of administration of the Department of Defence, and official, personal and social problems that military service personnel are likely to encounter in the performance of their everyday military routine. ${ }^{56}$ This includes an extension of its mandate to include:

- Maladministration within the affairs of the entire Department of Defence;

- Abuse or unjustifiable exercise of power by anyone in a commanding position that has or is likely to have a direct or indirect negative impact on a member of the military service;

- Undue delay, which is likely to have a direct or indirect negative impact on a member of the Defence Force;

- Complaints relating to working conditions in general - exemption from and postponement of obligatory military service and entitlement to benefits in case of disability suffered during operations or of death;

- Discrimination in the work environment;

- Harassment in all forms; and

- $\quad$ Systemic issues concerning broader policy questions. This at times, results from an investigation of an individual complaint that may shed light on systemic problems.

Every institution has its share of problems and challenges, but there are special ones endemic in a military organisation. Necessarily, military organisations have daunting power over their members, who are often called upon to undertake work that is both physically and mentally taxing - and at times even physically and mentally debilitating. ${ }^{57}$ This generates inordinate levels of stress that not only take a human toll, but can also impede the effectiveness of military institutions that are dependent on positive morale. ${ }^{58}$ Retention, recruitment, focus and effort all suffer. Problems and challenges can also be acute in a military institution because of the 'military culture', with its traditions of blind unquestioning obedience, of closed access to information and of a highly regimented command structure that relies on layers of fixed orders and directives. ${ }^{59}$ This creates a bureaucratisation unparalleled in civilian life. ${ }^{60}$ 
It is within this kind of organisation that the chain of command is taxed with work that is so crucial that it engages national security and international peace and justice. Officers given this kind of responsibility acquire an understandable zeal to do their job well. ${ }^{61}$ Unfortunately, some of those who take on commitments of this magnitude can become single-minded, even blinkered; in extreme cases treating human beings as mere troops or military tools without rights - abstracting them and forgetting their humanity. ${ }^{62}$ Administration can become wooden, rule-bound and order-obsessed, even when those rules and orders reveal themselves as problematic and there are means of remedy available. In a misguided effort to maintain the authority they need to do their job, military institutions can become closed and resistant to change. ${ }^{63}$ It is also notorious that military organisations tend to be conservative. In a Canadian report entitled Achieving administrative efficiency, a Minister's Advisory Committee spoke of a "cultural aversion to programmatic risk" that feeds "resistance to all but the most incremental change". ${ }^{64}$ When change is advocated in a conservative institution, an entrenched 'no can do' attitude can too easily undermine initiative and progress. ${ }^{65}$ This can put a premium on keeping problems from the public eye so that meddlesome political interference or public criticism does not undermine the mission. In the faith that they are internal matters best handled within the command structure, military organisations are often apt, in the face of criticism, to circle the wagons. ${ }^{66}$

So, when soldiers have real problems and are treated unfairly, they can run into unreasonably rigid administrators working within a closed, highly bureaucratic, conservative and, at times, even insensitive institution. ${ }^{67}$ They can run into bias and stereotype. What makes the problems so intransigent is that those who give short shrift to these problems do so with the authority of their own consciences. ${ }^{68}$ The contributions that an impartial, outside agency can make are obvious, given that problems often emerge from a widespread culture of defensiveness within a largely closed society. Consequently, having an MO to address their challenges can ease a great deal of burden and build confidence and trust, knowing there is an independent mechanism exercising fair and balanced military oversight.

The object of the Act

Clearly the manner on which the object of the Military Ombud Act has been phrased has illustrated the omission on the part of the drafters of what constitute the founding basis for such an important institution within the defence sector. The authors view the establishment of the South African MO not likely to provide any solutions to the deep-rooted problems experienced by those directly or indirectly related to the defence sector. In order for the Ministry of Defence to ensure that it 
addresses these issues through the MO, it needs to ensure that shortcomings found in the Act are adequately dealt with. The objective of the MO office is to investigate and ensure that complaints are resolved in a fair, economical and expeditious manner. The said objective, in our view, lacks substance as to the critical establishment of the MO and needs to be concretised by expressly strengthening the objective of the MO to include its competency to:

- Independently and impartially investigate and ensure a fair, economical and expeditious resolution of complaints;

- Exercise democratic control over the defence sector;

- Ensure respect for the rule of law in the defence sector;

- $\quad$ Promote transparency and accountability within the defence structures;

- Focus attention on systemic problems in military practice requiring corrective action;

- Enhance the efficiency, effectiveness and proper administration of the defence sector; and

- Strengthen the confidence of both the public and the defence sector personnel in the Department of Defence.

Units deployed in international operations

This aspect is not covered in the Act and to ensure that such units are covered by the MO jurisdiction, a provision should be made to incorporate such missions by outlining a procedure to be followed in initiating investigations of personnel involved, without compromising the mission concerned but ensuring a thorough and smooth investigation and that communications channels are established and followed. Examples are informing the contingent commander, keeping him or her informed or the commander appointing the liaison person to deal with the MO. Provision should also be made to enable the MO to visit the operations theatre if necessary. The same investigation procedure that has been deployed in domestic operations should also be established for a unit.

\section{Limitations on the MO's jurisdiction}

In terms of the Act it is not clear as to whether there are any limitations to the MO's investigations, for example, whether labour- and employment-related complaints are also to be dealt with by the MO. The Act should have clarified this aspect, although caution should be exercised not to make the MO a labour and employment investigator. However, the possibility of certain labour- and employment-related trends drawing the attention of the MO due to their nature, scope and extent cannot be ruled out, provided the internal complaints process has 
been fully dealt with. In addition to the abovementioned shortcomings of the Act, there appears to be a critical independence aspect that has not been adequately dealt with in the Military Ombud Act.

\section{Determination of the South African MO's Independence}

The independence of the MO office is crucial for ensuring the robust and credible accountability of the military. In order to be independent, the MO should firstly be granted statutory authority, financial, operational independence and an adequate staff. ${ }^{69}$ This means, firstly, that an appropriate legal status should be granted to the MO office, either by the constitution ${ }^{70}$ or by legislation, ${ }^{71}$ or by both instruments. $^{72}$ Secondly, the MO should be provided with his or her own autonomous own investigative capacity. ${ }^{73}$ Thirdly, the MO should be provided with sufficient and qualified expert staff. ${ }^{74}$ The MO's independence also depends on institutional embedding in the political system, which varies from country to country. In some countries, an MO is appointed by and is accountable to Parliament. ${ }^{75}$ In others, ombudsmen are appointed by the Ministry of Defence and accountable to the Ministry of Defence and to Parliament (e.g. in Canada). ${ }^{76}$ Ombudsmen may also be appointed by and report to the commander of the armed forces (e.g. in Estonia). The independence of the MO is one of its main strengths and a source of trust; therefore, the MO should never serve as an adviser to ministers or to Parliament. ${ }^{77}$ In this sense, MO institutions possess two types of independence, namely institutional independence and operational independence. ${ }^{78}$

\section{Institutional independence}

Institutional independence is important in order for an ombudsman institution to be effective, meaning that the MO's recommendations are followed by the relevant organs. ${ }^{79}$ The MO's independence must be guaranteed by law and, where applicable, by the constitution. These statutory provisions typically dictate that there can be no interference from the executive, and in states such as Sweden and Finland not even Parliament may issue instructions to the MO ${ }^{80}$ An additional dimension of institutional independence is the security of the MO's position and tenure in office: a legally established tenure of office, clear procedures for the potential removal of an ombudsperson from office and formal criteria stipulating the circumstances under which this can happen. In the majority of states included in this research, the institution responsible for the removal of the MO from office is Parliament. However, in the UK, the Netherlands, Belgium and Ireland, the ombudsman institution for the armed forces may be removed by the Minister of 
Defence. This is the backdrop of having/involving the Ministry of Defence in the administration or operation of the MO.

The South African MO, as stated above, has been established in accordance with national legislation: the Military Ombud Act - similar to Finland. To a certain extent it could be argued that it has complied with the first element of the independence. It is the authors' view that the current Act does not expressly mention his or her term to be an exclusive fulltime capacity ${ }^{81}$. In many states, the MO is also obliged to take steps to ensure his or her independence. Legal obligations require the MO to abstain from activities that might give rise to a conflict of interests, thus compromising his or her independence. These provisions include the following prohibitions: engaging in any other professional activities (Serbia), membership of political parties (Serbia and Estonia) and the holding of a state or local government position (Estonia). Thus it is not clear from his or her appointment that this conflict of interest has been averted.

\section{Operational independence}

In most cases, the mechanism that guarantees operational independence of the MO is the capacity to launch its so-called own-initiative investigations, meaning that no request or complaint is required in order for an MO to address an issue. ${ }^{82}$ This is an important measure of independence, because if an ombudsman institution can undertake own-initiative investigations, its investigative activities are not contingent upon the decisions of other actors (e.g. Germany, Canada, Finland, Georgia and Ireland).

The majority of institutions examined in this study have the capacity to initiate their own investigations, with Belgium, Ireland and the UK being the only exceptions. An important corollary of the freedom to address issues deemed to merit investigation is the legally guaranteed right to pursue investigations to their conclusion, free from the interference of other institutions. More than half of the ombudsman institutions examined in this research stated that their investigations cannot be terminated or suspended by any other body. However, in several other cases the ombudsman institutions' investigations may be suspended or terminated, for example by the Parliamentary Defence Committee (Germany), the Minister of Defence (Canada) or the Court (Belgium). While, in theory, these institutions may halt the work of the MO institutions in the states mentioned, in practice this has never happened. As part of his or her investigative duties, the MO may deal with individual wrongs, as well as with systemic issues concerning broader policy questions. $^{83}$ 
With regard to the South African MO, several shortfalls can be identified in the Military Ombud Act. Section 6 of the Act seems to deny the MO the important power/independence to proactively conduct his or her own-initiative/systematic investigations. Any organisation/institution intending to establish a watchdog institution (ombudsman) needs to be mindful of the need not to make the impending agency a toothless tiger. ${ }^{84}$ Therefore, in order for the South African MO to be independent, impartial and perform his or her investigation powers fully, without any fear, favour or prejudice, the Military Ombud Act should enable the MO, if in his or her opinion there seems to be systematic problems within the defence sector that has not yet been brought to his or her attention, to institute and complete owninitiative investigations. Evidently, the Act intends to dispossess the Public Protector of all its investigation powers, from which it was capable on its own to conduct such own-initiative investigations. ${ }^{85}$ Extension, therefore, of the MO's powers to include own-initiative investigations in respect of a broad spectrum of complaints would enable and empower him or her to have requisite operational independence and a wider scope of investigation similar to that which the Public Protector had over the Department of Defence. By so doing, the Act would have lawfully dispossessed the Public Protector of the said investigative powers, while ensuring a smooth transfer of the jurisdiction to the MO and the continuation of the said jurisdictional powers.

\section{Reporting mechanisms}

In Canada, upon conclusion of an investigation, the MO may make recommendations to the Minister of Defence, setting out measures that should be taken to rectify the situation. In instances where the Minister's response to the MO's recommendations did not provide for the required corrective action, the MO has the power to issue a special report on the case. ${ }^{86}$ The Military Ombud Act has now adopted a recommendation route instead of a directive stand in the Bill, where the MO was likely to order the Minister to comply with his or her determinations. ${ }^{87}$ This is seen as a retrogressive step towards ensuring full compliance with the MO's findings. In terms of the Military Ombud Act, the MO is required to report to the Minister annually, ${ }^{88}$ who will subsequently table the MO's report before Parliament. ${ }^{89}$ This position is found to be retrogressive, unlike the proposed Bill, which proposed simultaneous reporting to the Public Protector. ${ }^{90}$

The authors view the current reporting mechanism in the Act to be a ticking time bomb for the said MO, with adverse results, as accountability has apparently already been compromised. In terms of Section 5 of the Act, the MO must be appointed by the President, and the question needs to be asked why then will the MO be required to report to the Minister. ${ }^{91}$ This is argued to be likely to compromise 
the independence of the MO, as his or her reporting directly to the Minister is likely to have serious repercussions, in particular to matters that may directly and indirectly relate to the Minister in the course of his or her duties. Rather, because the MO is to be appointed by the President, the President must direct that the existing Parliamentary Portfolio Committee on Defence and Military Veterans be the appropriate body to which the MO must directly report to. Further, contrary to Section 11 of the Act, the MO must directly and personally present his or her report to the said parliamentary committee and, due to his or her independence, the MO must also serve his or her report simultaneously and directly to the Minister and the Public Protector. Although the South African MO needs to draw inspiration from the mentioned countries, it should not be a blind/single adoption of one approach but a well-thought hybrid approach. In other words, the fact that countries such as Canada have their MO appointed by Cabinet but reporting to the Minister does not mean that SA must follow. The authors regard the MO's independence as more effective and efficient if he or she reports to a body operating outside the domain of the military sector or the Minister of Defence.

This approach is likely to ensure that the defence sector takes the MO's oversight function seriously and puts pressure on the sector to comply with the MO's recommendations, as the MO would be accountable to Parliament, as opposed to the Minster. Once an investigation has been completed, the MO has the power to make recommendations to eliminate improper conduct; including demanding a change in policy or the adoption of certain measures to ensure that there is no recurrence. $^{92}$ In most states, however, ombudsman institutions do not have binding adjudicative powers; instead, they rely merely on persuasion. Their recommendations carry significant political weight and moral authority. Accountability of the MO to the Portfolio Committee would further strengthen its stance, which will ensure that its recommendations are implemented and independently monitored, unlike when the MO directly reports to the Minister, who determines the MO budget.

\section{Budgetary independence}

Budgetary independence, on the other hand, means that an ombudsman institution obtains and manages its funds independently from any of the institutions over which it has jurisdiction. ${ }^{93}$ Although the independence of the MO is affirmed by the MO having to appoint his or her staff without consulting the Minister, ${ }^{94}$ the authors find it contradictory for the MO to now deliberate salaries of his or her staff with the Minister in addition to the Minister of Finance. ${ }^{95}$ The majority of ombudsman institutions examined in this research have their own budgets, allocated 
to them by Parliament. However, similarly to the South African MO, ${ }^{96}$ a number of the MO institutions, including those of the UK, Belgium, the Netherlands, Ireland and Belgium, receive their budgets from their ministries of Defence. ${ }^{97}$ To date, R5 million has already been allocated by the Minister to establish the South African MO office. ${ }^{98}$ Of crucial importance is the staff of MO office. Ideally, this should consist of civilians whose expertise should allow the MO office to carry out research and formulate legal opinions independent of other government departments. Some

of these institutions pointed out that their reliance upon the executive for resources has negative consequences for their independence and the performance of their functions.

\section{Conclusions and the Way Forward}

From the abovementioned comparative analysis it can be deduced that for the South African MO office to realise its full potential, there are certain essentials that need to be revisited and strengthened, namely the identified gaps, the MO's independence and political authority, and an adequate material/intellectual infrastructure.

Based on the ombudsman institutions examined in this study, concrete recommendations for strengthening the MO's role should include adequate attention to the following:

- Resources to increase the available financial and human resources;

- Organisational reforms to introduce better case handling and monitoring systems and to introduce a continuous staff training programme to develop expertise and more task specialisation within the office of the ombudsman institution;

- Awareness raising by introducing programmes that would generate greater awareness among the public, civil servants and personnel of the armed forces about the role and the powers of the MO; and

- International cooperation strengthened by exchanging knowledge and experiences with counterparts abroad.

Ombudsman institutions should have a strong constitutional and statutory footing; the applicable Act must articulate a clear mandate for the institution and stipulate the powers and methods at its disposal for exercising this mandate. There should be a clear understanding of the constitutional and legal position of the ombudsman institution vis-à-vis other relevant stakeholders. 
Investigating and making recommendations about complaints are central to the mandate of the MO and, as repeatedly mentioned, the MO should have the power to propose changes in legislation and policy in order to bring about long-term changes to the practices that give rise to problems within the armed forces.

It is essential that the complainants and the defence establishment see the MO as impartial and neutral, resulting in a greater willingness to voluntarily accept and implement the results of investigations and recommendations.

In conclusion, of interest to note in the Military Ombud Act is the increased non-renewable term of the MO from five years to a period of seven years as well as the MO's jurisdictional limitations to now include matters pending before any other dispute-resolution body.

\section{Endnotes}

${ }^{1}$ Ruppel-Schlichting, KG. "The independence of the Ombudsman in Namibia". $<$ http://www.kas.de/upload/auslandshomepages/namibia/Independence_Judi ciary/ruppel-schlichting.pdf > Accessed on 9 September 2011.

${ }^{2}$ South Africa opted to use the term 'Military Ombud', possibly for the sake of gender-sensitivity, while other countries hereto referred utilise the term 'Ombudsman' for military and civilian purposes, as referred to in this article. The terms are hence used interchangeably in this article.

${ }^{3}$ Republic of South Africa (RSA). Military Ombud Act No. 4 of 2012. Pretoria: Government Printer, 2012.

${ }^{4}$ RSA. Public Protector Act No. 23 of 1994, as amended. Pretoria: Government Printer, 1994, Section 6(4).

${ }^{5}$ RSA. Military Ombudsman Bill of 2011. Pretoria: Government Printer, 2011.

${ }^{6}$ South African Government Information. "The SANDF's first Military Ombudsman sworn in". 15 May 2012.

<http://www.info.gov.za/speech/DynamicAction?pageid=461\&sid=27502\&t id=68564 > Accessed on 19 January 13. Rakoma, A. "South Africa's first Military Ombudsman sworn-in". 16 May 2012. <http://www.dod.mil.za/news/2012/05/military_ombudsman.htm> Accessed on 2 May 2013.

${ }^{7}$ Military Ombud Act op. cit.

${ }^{8}$ Geneva Centre for the Democratic Control of Armed Forces (DCAF). Military Ombudsman. Geneva, 2005, 1.

${ }^{9}$ Fleck, D. The handbook of humanitarian law in armed conflicts. Oxford: Oxford

${ }^{10}$ Ibid. University Press, 1995, 32. 
${ }^{11}$ Britt, TW, Castro, CA \& Adler, AB. Military life: The psychology of serving in peace. Westport, CT: Greenwood Publishing Group, 2005, p. 78.

${ }^{12}$ DCAF op. cit.

${ }^{13}$ Schlueter, DA. Military criminal justice: Practice and procedure. Charlottesville, VA: LexisNexis, 2004, p. 14.

${ }^{14}$ Leigh, I, Born, H, Lazzarini, C \& Clements, I. Handbook on human rights and fundamental freedoms of armed forces personnel. Warsaw: Office for Democratic Institutions and Human Rights (ODIHR), 2008, p. 230.

15 Vashakmadze, M. Guidebook: Understanding military justice. Geneva: DCAF, 2010, p. 9.

${ }^{16}$ Leigh et al. op. cit., p. 231.

${ }^{17}$ Ibid., p. 230.

${ }^{18}$ Ibid., p. 231

19 Hossain, A. Ombudsman for Bangladesh: Theory and reality. Bangladesh: University of Rajshahi Press, 2009, p. 18.

${ }^{20}$ Andreu-Guzman, F. Military jurisdiction and international law, Part I. Geneva: ${ }^{21}$ Ibid. International Commission of Jurists, 2004, p. 157.

${ }^{22}$ Ibid.

${ }^{23}$ Nolte, G. European military law systems. Berlin: De Gruyter Recht, 2003, p. 98.

24 Rowe, P. The impact of human rights law on armed forces. Cambridge: Cambridge University Press, 2006, p. 21.

${ }^{25}$ Fleck op. cit., p. 85 .

${ }^{26}$ Born, H, Fluri, P \& Johnsson, A. Handbook on parliamentary oversight of the security sector: Principles, mechanisms and practices. Geneva: DCAF, 2003, 45.

${ }^{27}$ Detter, I. The law of war. $2^{\text {nd }}$ ed. Cambridge: Cambridge University Press, 2000, p. 30.

${ }^{28}$ Caforio, G. Handbook of the sociology of the military. New York: Kluwer Academic/Plenum Publishers, 2003, p. 65.

${ }^{29}$ Ibid.

${ }^{30}$ Careiras, H. Gender and the military: Women in the armed forces of Western democracies. London: Routledge, 2006, p. 18.

${ }^{31}$ Ibid.

${ }^{32}$ Ibid.

${ }^{33}$ Ibid.

${ }^{34}$ Callaghan, J \& Kernic, F. Armed forces and international security: Global trends and issues. Münster: Lit Verlag, 2003, p. 39.

${ }^{35}$ Careiras op. cit., p. 18.

${ }^{36}$ Ibid.

${ }^{37}$ Ibid.

${ }^{38}$ Caforio op. cit., p. 23.

${ }^{39}$ Ibid.

${ }^{40}$ Ibid.

${ }^{41}$ Ibid., p. 22. 
${ }^{42}$ Fleck op. cit., p. 15.

${ }^{43}$ Careiras op. cit., p. 39.

${ }^{44}$ Detter op. cit., p. 62.

${ }^{45}$ Careiras op. cit., p. 39.

${ }^{46}$ Detter op. cit., p. 29.

${ }^{47}$ Ibid.

48 Reif, LC. Promotion of international human rights law by the office of the ${ }^{49}$ Ibid. ombudsman. The Hague: Kluwer Law International, 1999, p. 271.

${ }^{50}$ Waseem, M. "Independence of Ombudsmen". In Asian Development Bank (ed.). Strengthening the Ombudsman Institution in Asia: Improving accountability in public service delivery through the Ombudsman. 2011, 82. <http://cprid.com/policy\%20area/policy\%20areas/good\%20governance\%20 2.pdf $>$ Accessed on 1 May 2013.

51 Gottehrer, DM \& Hostina, M. "Essential characteristics of a classical ombudsman". $\quad 8 \quad$ April 1998. <http://www.usombudsman.org/documents/PDF/References/Essential.PDF> Accessed on 15 August 2011.

52 RSA. Constitution of the Republic of South Africa, No. 108 of 1996. Pretoria: Government Printer, 1996, Section 195(1), (2), (3).

${ }^{53}$ RSA, Military Ombudsman Bill op. cit.

${ }^{54}$ Careiras op. cit., p. 44.

${ }^{55}$ RSA, Military Ombud Act op. cit., Section 4(1).

${ }^{56}$ Callaghan \& Kernic op. cit., p. 38.

${ }^{57}$ Careiras op. cit., p. 98.

${ }^{58}$ Ibid.

${ }^{59}$ Ibid.

${ }^{60}$ Ibid.

${ }^{61}$ Hyson, S. Specialty ombudsman offices: The new breed of structural heretics. Ottawa: University of New Brunswick, 2009, p. 7.

${ }^{62}$ Caforio op. cit., p. 45.

${ }^{63}$ Ibid.

${ }^{64}$ Advisory Committee on Administrative Efficiency. Achieving administrative efficiency. Report to the Minister of National Defence, Ottawa, 2003.

${ }^{65}$ Rowe op. cit., p. 60.

${ }^{66}$ Ibid.

${ }^{67}$ Quaker Council for European Affairs. The right to conscientious objection in Europe: A review of the current situation. Brussels: Quaker Council for European Affairs, 2005, 29.

${ }^{68}$ Pegram, T. "Accountability in hostile times: The case of the Peruvian Human Rights Ombudsman 1996-2001". Journal of Latin American Studies 40. 2008. 51.

${ }^{69}$ Waseem op. cit., pp. 62-63, 66-67, 69-70, 73-74, 78-7. 
70 Azerbaijan-Moskos, CJA, Williams, J \& Segal, D. The post-modern military: Armed forces after the Cold War. Oxford: Oxford University Press, 2000, 20; Waseem op. cit., p. 82.

${ }^{71}$ For example Finland; Ombudsman for the Defence Forces. Annual Report. 2009. <http://www.theioi.org/europe/ireland/ombudsman-for-the-defence-forces> Accessed on 23 May 2013.

${ }^{72}$ For example Denmark.

73 Carmona GV. "Strengthening the Asian Ombudsman Association and the Ombudsman institutions of Asia". In Asian Development Bank op. cit. pp. 15-16; Wing-Hung Lo, C, Yee, HWH, Liu, NN \& Li, H. "Ombudsman and stakeholder engagement for improved service delivery". In Asian Development Bank op. cit., pp. 107, 146; Marin, A \& Jones, G. "Measuring ombudsman performance: Setting performance standards and indicators". In Asian Development Bank op. cit., p. 202.

${ }^{74}$ Azerbaijan-Moskos et al. op. cit.

${ }^{75}$ For example Poland, Norway and the Czech Republic.

${ }^{76}$ Azerbaijan-Moskos et al. op. cit., p. 12.

${ }^{77}$ Ibid.

${ }^{78}$ Caforio op. cit., p. 23.

${ }^{79}$ Ombudsman for the Defence Forces op. cit., p. 14.

${ }^{80}$ Leigh et al. op. cit., p. 230.

${ }^{81}$ RSA, Public Protector Act op. cit., Section 13(b).

${ }^{82}$ Detter op. cit., p. 30.

${ }^{83}$ Fleck op. cit., p. 59.

${ }^{84}$ Hartley, W. "Military Ombudsman Bill off to rocky start", Business Day. 18 August 2011. p. 4.

${ }^{85}$ RSA, Public Protector Act op. cit., Section 7(1) (a).

${ }^{86}$ Careiras op. cit., p. 18.

${ }^{87}$ RSA, Military Ombud Act op. cit., Section 6(8); RSA, Military Ombudsman Bill op. cit., Section 6(6).

88 Department of Defence. "Defence Secretariat: Annual Performance Plan for 2012”.

<http://www.dod.mil.za/documents/app/2012/Def_Sec_APP\%20CD.pdf>

Accessed on 19 January 2013.

${ }^{89}$ RSA, Military Ombud Act op. cit., Section 11.

${ }^{90}$ RSA, Military Ombudsman Bill op. cit., Section 11(3).

${ }^{91}$ RSA, Military Ombudsman Bill op. cit., Section 11(1).

${ }^{92}$ Fleck op. cit., p. 57.

${ }^{93}$ Ibid.

${ }^{94}$ RSA, Military Ombud Act op. cit., Section 9(1).

${ }^{95}$ RSA, Military Ombud Act op. cit., Section 9(2).

${ }^{96}$ RSA, Military Ombudsman Bill op. cit., Section 10(1)

${ }^{97}$ Department of Defence op. cit.

${ }^{98}$ Ibid. 